\title{
UJI DAYA HAMBAT EKSTRAK BUAH KELOR (Moringa oleifera Lamk) TERHADAP PERTUMBUHAN JAMUR Candida albicans
}

\author{
Inhibitory Test of Extract of Moringa Fruit (Moringa oleifera Lamk) on \\ Growth of Fungus Candida albicans
}

\author{
*Siti Nuryanti, Kasmudin Mustapa, dan I Gede Sudarmo \\ Pendidikan Kimia/FKIP - Universitas Tadulako, Palu - Indonesia 94118 \\ Received 09 September 2016, Revised 10 October 2016, Accepted 11 November 2016
}

\begin{abstract}
Moringa (moringa oleifera lamk) is a nutritious plant that can cure various diseases. Part of this plant such as leaves, roots, flowers, and fruits serve as a traditional medicine. The aim of this study is to determine the inhibitory of extract of moringa fruit on the growth of the fungus candida albicans. The extract of moringa fruit is made by using several solvents such as distilled water, ethanol and hexane. Suspension of the candida albicans obtained from Clinical Laboratory, Palu, Central Sulawesi. Suspension of the candida albicans is synchronized with Mc. Farland solution. The fungus test uses a pitting method. The results showed that inhibition of extract of moringa fruit on the growth of the fungus candida albicans with solvents of distilled water provides greater results as compared with ethanol and hexane. Based on the results of the observation, the percentage of inhibition of the extract of moringa fruit on the growth of the fungus candida albicans with various solvents are $100 \%$ for distilled water, 59.99\% for ethanol and $6.97 \%$ for hexane. The result of phytochemical screening test showed that the moringa fruit contains alkaloids, flavonoids and steroids.
\end{abstract}

Keywords: Moringa fruit extract, the inhibition of the fungus, Candida albicans

\section{Pendahuluan}

Indonesia merupakan negara dengan kekayaan alam yang melimpah. Hampir segala jenis tumbuhan dapat tumbuh di wilayah negara ini. Sebagian besar sudah dimanfaatkan sejak nenek moyang kita untuk mengobati berbagai penyakit. Tumbuhan-tumbuhan tersebut dalam penggunaannya dikenal dengan obat tradisional (Sjahid, 2008).

Pengetahuan tentang pengobatan tradisional telah diwariskan dari satu generasi kegenerasi berikutnya melalui resep nenek moyang, adat istiadat dan kepercayaan setempat. Salah satu tanaman yang dapat berpotensi sebagai obat di kalangan masyarakat adalah tanaman kelor. Kelor merupakan tanaman perdu dengan tinggi 10 meter, berbatang lunak dan rapuh, daun sebesar ujung jari berbentuk bulat telur dan tersusun majemuk (Krisnadi, 2012). Bagian dari tanaman ini seperti daun, buah, bunga, biji dan akar dapat dimanfaatkan sebagai obat. Menurut Tilong (2012), daun kelor mengandung pterigospermin yang bersifat merangsang kulit Siti Nuryanti

Program Studi Pendidikan Kimia, Fakultas Keguruan dan Ilmu Pendidikan, Universitas Tadulako

email: sitinoer_untad@yahoo.com

Published by Universitas Tadulako 2016 sehingga dapat mengobati kelemahan anggota tubuh seperti tangan dan kaki. Jika daun segarnya dilumatkan, maka dapat mengurangi rasa nyeri karena bersifat analgesik. Buahnya berkhasiat sebagai antimikroba, antiinflamasi, dan menjaga kesehatan reproduksi. Sayeed, dkk., (2012), melaporkan bahwa akar dan kulit kelor berguna dalam pengobatan panyakit jantung, mata, peradangan dan pembesaran limpa, serta bunganya dimanfaatkan untuk mengobati penyakit otot dan ulkus kusta.

Kelor juga kaya akan sumber antioksidan alami yang baik karena mengandung berbagai jenis senyawa antioksidan seperti asam askorbat, flavonoid, phenolic dan karotenoid. Tingginya konsentrasi asam askorbat, zat estrogen dan $\beta$-sitosterol, besi, kalsium, fosfor, tembaga, vitamin A, B dan C, $\alpha$-tokoferol, riboflavin, nikotinik, asam folat, piridoksin, $\beta$-karoten, protein, dan khususnya asam amino esensial seperti metionin, sistin, triptofan dan lisin terdapat dalam daun dan polong yang membuatnya menjadi suplemen makanan yang hampir ideal (Fahey, 2005). Berdasarkan penelitian sebelumnya telah dilaporkan bahwa daun kelor mengandung senyawa metabolit 
sekunder flavonoid, alkaloid, fenol yang juga dapat menghambat aktivitas bakteri (Pandey, dkk., 2012). Biji kelor mengandung senyawa tanin dan saponin yang berfungsi sebagai antibakteri (Nepolean, dkk., 2009). Alkaloid mempunyai aktivitas antijamur dengan cara mengganggu komponen penyusun peptidoglikon pada sel jamur sehingga lapisan dinding sel tidak terbentuk secara utuh dan menyebabkan kematian sel tersebut (Robinson, 1995).

Flavonoid sendiri merupakan golongan terbesar dari senyawa fenol, senyawa fenol memiliki sifat efektif menghambat pertumbuhan virus, bakteri dan jamur. Mekanisme kerja flavonoid dalam menghambat jamur bekerja dengan cara denaturasi protein sehingga meningkatkan permeabilitas membran sel. Denaturasi protein menyebabkan gangguan dalam pembentukan sel sehingga merubah komposisi komponen protein, sehingga dengan terganggunya membran sel dapat menyebabkan meningkatnya permeabilitas sel sehingga menyebabkan kerusakan sel jamur. Kerusakan tersebut dapat menyebabkan kematian sel jamur (Rahayu, 2013).

Candida albicans adalah anggota flora normal terutama saluran pencernaan, juga selaput mukosa saluran pernapasan, vagina, uretra, kulit dan di bawah jari-jari kuku tangan dan kaki. Candida albicans kadang-kadang dapat menyebabkan penyakit sistematik progresif pada penderita yang lemah atau sistem imunnya tertekan, terutama jika imunitas berperantara sel terganggu. Candida albicans dapat menimbulkan invasi dalam aliran darah, tromboflebitis, endokarditis, atau infeksi pada mata dan organ-organ lain bila dimasukan secara intravena (kateker, jarum, hiperalimentasi, penyalahgunaan narkotika dan sebagainya (Simatupang, 2009).

Penelitian mengenai uji daya hambat pertumbuhan anti mikroba dengan memanfaatkan ekstrak tumbuhan telah banyak yang melakukan, seperti penelitian yang dilakukan oleh Dhayanti, dkk., (2012) meneliti tentang efek antimikroba ekstrak n-Heksana daun kelor terhadap Esherichia coli secara in vitro. Berdasarkan penelitian diperoleh bahwa ekstrak n-heksana daun kelor mengandung minyak atsiri, saponin, polifenol, dan flavonoid yang memberikan efek antimikroba pada konsentrasi bunuh minimal 35\% terhadap Esherichia coli secara in vitro.

Widowati, dkk., (2014) juga meneliti tentang uji aktivitas antibakteri ekstrak daun kelor terhadap bakteri pembusuk ikan segar
(Pseudoonas aeruginosa). Berdasarkan hasil penelitian yang dilakukan diperoleh bahwa ekstrak daun kelor mengandung senyawa triterpenoid, saponin, tanin dan flavonoid yang berfungsi sebagai antibakteri terhadap (Pseudomonas aeruginosa) bakteri pembusuk ikan segar.

Tulisan ini mendeskripsikan penelitian tentang uji daya hambat ekstrak buah kelor terhadap pertumbuhan jamur Candida albicans.

\section{Metode}

\section{Alat dan Bahan}

Alat-alat yang digunakan dalam penelitian meliputi: neraca digital (Kern kb), gelas ukur $100 \mathrm{~mL}$, gelas ukur $1000 \mathrm{~mL}$, gelas kimia 250 $\mathrm{mL}$, gelas kimia $100 \mathrm{~mL}$, labu ukur $50 \mathrm{~mL}$, labu ukur $100 \mathrm{~mL}$, tabung reaksi, rak tabung reaksi, corong pisah, batang pengaduk, jarum ose, vortex (Gemmy), penangas listrik (Barnstead), plastik tahan panas, alat penggiling, erlenmeyer $200 \mathrm{ml}$, erlenmeyer $500 \mathrm{ml}$, shaker orbital (Gerhandti), pipet tetes, autoklaf (Allamerican), incubator (Eyela LTI-700), cawan petri, blender, magnetik stirrer (Eyela), pinset, spatula, aluminium foil, tissue, gunting, jangka sorong dan penggaris.

Bahan-bahan yang digunakan meliputi: etanol 70\% (Merck), aquades, heksana (Teknis), kertas label, jamur candida albicans, media NA (Nutrien agar), media NB (Nutrien broth), larutan Mc. Farland, kertas saring, buah kelor muda, larutan $\mathrm{HCl}$ pekat (Mercki), logam $\mathrm{Mg}$, larutan $\mathrm{H}_{2} \mathrm{SO}_{4}$ pekat (Merck) dan reagen Mayer.

\section{Prosedur Penelitian}

Preparasi Sampel

Buah kelor yang masih segar lalu dicuci dengan bersih dan dikeringkan dengan cara diangin-anginkan selama 7 hari (1 minggu). Kemudian buah kelor yang telah kering diblender dan digiling sehingga menjadi serbuk.

\section{Uji Metabolit Sekunder}

Sebanyak 30 gram serbuk buah kelor ditimbang dan dimasukan ke dalam tiga buah erlenmeyer. Setelah itu sebanyak $100 \mathrm{~mL}$ aquades ditambahkan pada erlenmeyer I, 100 $\mathrm{mL}$ etanol $70 \%$ pada erlenmeyer II, dan 100 $\mathrm{mL}$ heksana pada erlenmeyer III. Selanjutnya ketiga erlenmeyer tersebut ditutup dengan aluminium foil dan dishaker selama 24 jam. Setelah itu, ketiga campuran disaring untuk memisahkan antara residu dan filtrat. Filtrat yang diperoleh digunakan untuk uji metabolit sekunder. 


\section{Uji Jamur Candida albicans}

Sebanyak 100 gram serbuk buah kelor ditimbang dan dimasukan ke dalam tiga buah erlenmeyer. Setelah itu sebanyak $300 \mathrm{~mL}$ aquades ditambahkan pada erlenmeyer I, 300 $\mathrm{mL}$ etanol $70 \%$ pada erlenmeyer II, dan 300 $\mathrm{mL}$ heksana pada erlenmeyer III. Selanjutnya ketiga erlenmeyer tersebut ditutup dengan aluminium foil dan dishaker selama 24 jam. Setelah itu, ketiga campuran disaring untuk memisahkan residu dan filtrat. Filtrat yang diperoleh digunakan untuk uji daya hambat pertumbuhan jamur candida albicans.

\section{Uji Metabolit Sekunder Ekstrak Buah Kelor}

Pengujian senyawa alkaloid dan flavonoid didasarkan pada penelitian yang telah dilakukan oleh Mustikasari \& Ariyani (2010). Tahapan pengujiannya dijelaskan sebagai berikut :

\section{Uji Alkaloid}

Diambil masing-masing sebanyak $2 \mathrm{~mL}$ sampel buah kelor yang telah diekstraksi dengan pelarut air, etanol $70 \%$ dan heksana ke dalam masing-masing 3 buah tabung reaksi yang berbeda. Setelah itu masing-masing ekstrak ditambahkan 3 tetes asam klorida pekat dan 5 tetes reagen Mayer. Jika masing-masing larutan terbentuk endapan putih maka sampel positif mengandung alkaloid.

\section{Uji Flavonoid}

Diambil masing-masing sebanyak $2 \mathrm{~mL}$ sampel buah kelor yang telah diekstraksi dengan masing-masing pelarut air, etanol $70 \%$, dan heksana. Kemudian dipanaskan kurang lebih 5 menit. Setelah dipanaskan masing-masing ditambahkan dengan 0,1 gram logam $\mathrm{Mg}$ dan 5 tetes $\mathrm{HCl}$ pekat. Jika masing-masing larutan terbentuk warna kuning jingga sampai merah, maka positif mengandung flavonoid.

Pengujian senyawa terpenoid dan steroid didasarkan pada penelitian yang telah dilakukan oleh Septianingsih (2013). Adapun tahapan penelitiannya sebagai berikut :

\section{Uji Terpenoid}

Diambil masing-masing sebanyak $2 \mathrm{~mL}$ sampel buah kelor yang telah diekstraksi dengan pelarut air, etanol 70\% dan heksana. Setelah itu masing-masing ekstrak, ditambahkan dengan 3 tetes $\mathrm{HCl}$ pekat dan 1 tetes $\mathrm{H}_{2} \mathrm{SO}_{4}$ pekat. Jika masing-masing larutan terbentuk warna merah atau ungu maka positif mengandung terpenoid. Uji Steroid

Diambil masing-masing sebanyak $2 \mathrm{~mL}$ sampel buah kelor yang telah diekstraksi dengan pelarut air, etanol $70 \%$ dan heksana. Setelah itu masing-masing ekstrak, ditambahkan dengan
3 tetes $\mathrm{HCl}$ pekat dan 1 tetes $\mathrm{H}_{2} \mathrm{SO}_{4}$ pekat. Jika masing-masing larutan terbentuk warna hijau maka positif mengandung Steroid.

\section{Sterilisasi Alat}

Alat-alat yang digunakan untuk uji jamur disterilkan dengan menggunakan autoklaf pada suhu $121^{\circ} \mathrm{C}$ selama 20 menit.

\section{Pembuatan media NA (Nutrien agar) dan NB (Nutrien Broth) \\ Pembuatan media NA (Nutrien agar)}

Pembuatan media NA (Nutrien agar) dilakukan dengan cara ditimbang sebanyak 7 gram natrium agar kemudian ditambahkan aquades sebanyak $250 \mathrm{~mL}$. kemudian dipanaskan sambil diaduk campuran tersebut sampai nutrien agar larut secara sempurna dan campuran menjadi jernih. Setelah itu diambil sebanyak $60 \mathrm{~mL}$ media yang telah dibuat dan dituangkan ke dalam enam cawan petri steril dan masing-masing cawan petri berisi $10 \mathrm{~mL}$ sebagai layer bawah. Kemudian cawan petriyang berisi media dibungkus dengan plastik tahan panas lalu disterilisasi selama 15 menit dengan menggunakan autoklaf pada suhu $121^{\circ} \mathrm{C}$ dan tekanan $1 \mathrm{~atm}$ sehingga menghasilkan media yang telah steril.

\section{Pembuatan media NB (Nutrien Broth)}

Pembuatan media NB (Nutrien Broth) dilakukan dengan cara ditimbang sebanyak 3,25 gram Nutrien Broth kemudian ditambahkan aquades sebanyak $250 \mathrm{~mL}$. setelah itu diambil media Nutrien Broth yang telah dibuat sebanyak $30 \mathrm{~mL}$ dan ditambahkan dengan jamur candida albicans sebanyak 5 ose dan disetarakan dengan kekeruhan larutan standar MC. Farland. Selanjutnya campuran dikocok dan divortex agar tercampur secara merata. Setelah itu diinkubasi selama 24 jam pada suhu $37^{\circ} \mathrm{C}$ di dalam inkubator sehingga menghasilkan media yang agak bening.

\section{Uji Daya Hambat Ekstrak Buah Kelor Terhadap Pertumbuhan Jamur Candida albicans}

Uji daya hambat ekstrak buah kelor dilakukan dengan cara diambil media nutrien agar yang telah dibuat sebanyak $150 \mathrm{~mL}$ dan dicampurkan dengan campuran (NB + jamur) dan dituang kedua campuran ke dalam enam cawan yang telah berisi nutrien agar dan masing-masing cawan sebanyak $30 \mathrm{~mL}$ sebagai layer atas. Setelah itu campuran didinginkan hingga campuran menjadi padat. Setelah media padat, dibuat lubang sumuran pada tengah cawan dengan menggunakan alat khusus yang berbentuk bulat (cetakan kue) dan diangkat 
bagian tengahnya dengan menggunakan pinset/spatula sehingga terbentuk sumuran sebagai tempat ekstrak buah kelor. Kemudian ditambahkan ekstrak buah kelor yang telah diekstraksi dengan pelarut aquades, etanol $70 \%$ dan heksana pada lubang sumuran yang telah dibuat $\pm 1 \mathrm{~mL}$ dan selanjutnya diinkubasi selama 24 jam pada suhu $37^{\circ} \mathrm{C}$ di dalam inkubator. Selanjutnya diamati dan diukur daya hambat ekstrak buah kelor dengan menggunakan jangka sorong.

\section{Hasil dan Pembahasan}

\section{Uji Metabolit Sekunder Ekstrak Buah Kelor}

Hasil penelitian yang telah dilakukan dalam pengujian metabolit sekunder pada ekstrak buah kelor dengan menggunakan beberapa pelarut yakni pelarut aquades, etanol $70 \%$ dan heksana dapat dilihat pada Tabel 1 .

Tabel 1 Hasil Uji Metabolit Sekunder Ekstrak Buah Kelor

\begin{tabular}{llcccc}
\hline \multirow{2}{*}{ No } & $\begin{array}{c}\text { Ekstrak buah kelor dalam } \\
\text { pelant }\end{array}$ & \multicolumn{4}{c}{ Hasil Pengujian } \\
\cline { 2 - 5 } & \multicolumn{1}{c}{ Allkaloid } & Flaronoid & Terpenoid & Steroid \\
\hline 1. Aquades & + & + & $\cdot$ & $\cdot$ \\
2. Etanol $70 \%$ & $\cdot$ & + & $\cdot$ & $\cdot$ \\
3. & Hekssma & $\cdot$ & $\cdot$ & $\cdot$ & + \\
\hline Keterangan $:(+)=$ ada, $(-)=$ tidak ada & & &
\end{tabular}

Pengujian alkaloid dilakukan dengan menggunakan reagen Mayer, dimana hasil positif yang dihasilkan yaitu endapan putih. Berdasarkan hasil penelitian pada Tabel 1 diperoleh bahwa ekstrak buah kelor dengan pelarut aquades positif mengandung alkaloid, sedangkan untuk pelarut etanol $70 \%$ dan heksana tidak mengandung alkaloid. Hal ini disebabkan karena tidak pecahnya dinding sel tumbuhan yang dianalisis, sehingga pada waktu melakukan ekstraksi tidak memberikan hasil yang sempurna. Hasil positif alkaloid pada uji Mayer ditandai dengan terbentuknya endapan putih. Diperkirakan endapan tersebut adalah kompleks kalium-alkaloid. Pembuatan pereaksi Mayer, larutan merkurium(II) klorida ditambah kalium iodida akan membentuk endapan merah merkurium(II) iodida. Jika kalium iodida yang ditambahkan berlebih maka akan terbentuk kalium tetraiodomerkurat(II) (Svehla, 1985). Uji alkaloid dengan pereaksi Mayer, diperkirakan nitrogen pada alkaloid akan bereaksi dengan ion logam $\mathrm{K}+$ dari kalium tetraiodomerkurat(II) membentuk kompleks kalium-alkaloid yang mengendap. Perkiraan reaksi yang terjadi pada uji Mayer ditunjukkan pada Gambar 1 dibawah ini :

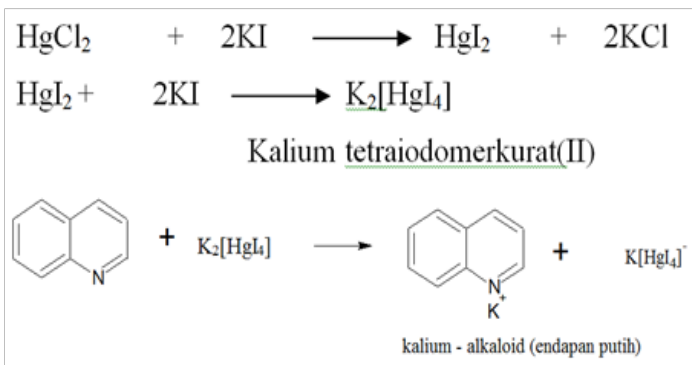

Gambar 1 Perkiraan Reaksi Uji Mayer (Marliana, dkk., 2005)

Hasil pengujian flavonoid dari ekstrak buah kelor dengan pelarut aquades dan etanol $70 \%$ yaitu terbentuknya larutan berwarna kuning yang menandakan adanya senyawa flavonoid. Fungsi dari pemanasan yaitu untuk melarutkan senyawa flavonoid, karena flavonoid dapat larut dalam air panas. Fungsi penambahan logam $\mathrm{Mg}$ dan $\mathrm{HCl}$ adalah untuk mereduksi inti benzopiron yang terdapat dalam struktur flavonoid sehingga terbentuk garam flavilium berwarna merah atau jingga. Flavonoid menurut strukturnya merupakan turunan senyawa induk flavon yang terdapat berupa tepung putih pada tumbuhan primula. Flavonoid merupakan senyawa yang mengandung dua cincin aromatik dengan gugus hidroksil lebih dari satu. Senyawa fenol dengan gugus hidroksil semakin banyak memiliki tingkat kelarutan dalam air semakin besar atau bersifat polar (Robinson, 1995), flavonoid berupa senyawa yang larut dalam air. Flavonoid dapat di ekstrak dengan etanol $70 \%$ dan tetap ada dalam lapisan air setelah ekstrak ini dikocok dengan eter minyak bumi (Harbone, 1987). Adapun reaksi pembentukan garam flavilium ditunjukkan pada Gambar 2.

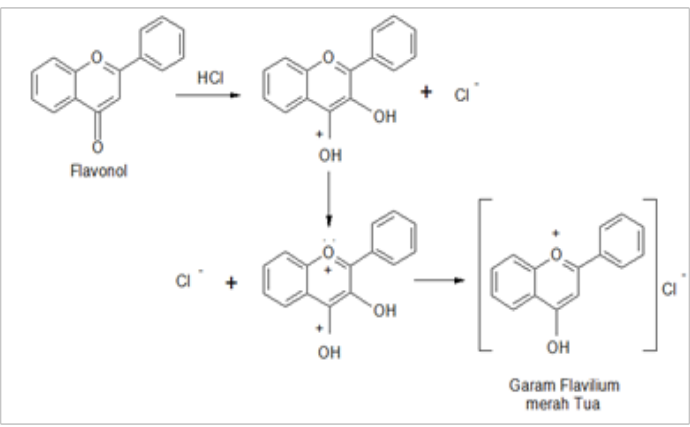

Gambar 2 Reaksi Pembentukan Garam Flavilium (Achmad, 1986)

Pengujian terpenoid dan steroid menggunakan reagen Liebermann-Burchad yaitu campuran antara $\mathrm{HCl}$ pekat dengan $\mathrm{H}_{2} \mathrm{SO}_{4}$ pekat. Analisis ini didasarkan pada kemampuan senyawa terpenoid dan steroid membentuk warna oleh $\mathrm{H}_{2} \mathrm{SO}_{4}$ pekat dalam 
pelarut asam klorida. Hasil positif diberikan pada sampel yang membentuk warna merah jingga untuk analisis triterpenoid dan hijau untuk analisis steroid (Sangi, dk k., 2008). Hasil dari pengujian senyawa terpenoid dan senyawa steroid pada masing-masing ekstrak buah kelor dengan pelarut aquades dan etanol $70 \%$ tidak terdapat senyawa terpenoid dan steroid dengan tidak adanya perubahan warna yang dihasilkan pada masing-masing ekstrak. Hasil yang diperoleh disebabkan karena penggunaan pelarut yang digunakan dalam proses ekstraksi merupakan pelarut yang bersifat polar dan semi polar. Sedangkan untuk ekstrak buah kelor dengan pelarut heksana terdapat senyawa steroid. Heksana merupakan pelarut yang bersifat nonpolar dan senyawa terpenoid dan steroid merupakan senyawa yang bersifat non polar sehingga senyawa-senyawa ini dapat terekstrak dengan sempurna pada pelarut tersebut.

\section{Uji Daya Hambat Ekstrak Buah Kelor Terhadap Pertumbuhan Jamur Candida albican.}

Penelitian uji daya hambat ekstrak buah kelor terhadap pertumbuhan jamur candida albicans menggunakan media nutrien agar dan nutrien broth serta dilakukan dengan cara sumuran. Metode sumuran dilakukan dengan membuat sumuran dengan diameter $3 \mathrm{~cm}$ pada media agar yang telah diinokulasi jamur candida albicans. Sumuran tersebut selanjutnya ditetesi ekstrak buah kelor dengan pelarut yakni aquades, etanol $70 \%$ dan heksana. Kemudian diinkubasi selama 1 x 24 jam pada suhu 37 oC. zona bening disekitar sumuran diukur untuk menentukan kemampuan daya hambat ekstrak buah kelor terhadap pertumbuhan jamur candida albicans yang ditandai dengan terbentuk zona bening disekitar sumuran. Hasil penelitian mengenai uji daya hambat ekstrak buah kelor terhadap pertumbuhan jamur candida albicans dapat dilihat pada Tabel 2.

Tabel 2 Hasil Uji Daya Hambat Ekstrak Buah Kelor Terhadap Pertumbuhan Jamur Candida albicans

\begin{tabular}{llc}
\hline N0 & Ekstrak Buah Kelor dalam Pelarut & Daya Hambat Jamur \\
\hline 1. & Aquades & $100 \%$ \\
2. & Etanol 70\% & $59,99 \%$ \\
3. & Heksana & $6,97 \%$ \\
4. & kontrol negatif(Aquades) & $15,79 \%$ \\
5. & kontrol negatif(Etanol 70\%) & $0 \%$ \\
6. & kontrol negatif(Heksana) & $0 \%$ \\
\hline
\end{tabular}

Berdasarkan hasil pada Tabel 2 terlihat bahwa ekstrak buah kelor dengan pelarut aquades memberikan presentasi daya hambat pertumbuhan jamur candida albicans paling besar dibandingkan dengan pelarut etanol $70 \%$ dan heksana. Presentase daya hambat ekstrak buah kelor dengan beberapa pelarut yaitu aquades, etanol $70 \%$ dan heksana berturutturut yaitu $100 \%, 59,99 \%$ dan 6,97\%, serta presentase kontrol negatif dengan beberapa pelarut yakni aquades, etanol $70 \%$ dan heksana berturut-turut yaitu $15,79 \%, 0 \%$ dan $0 \%$. Hasil uji daya hambat ekstrak buah kelor terhadap pertumbuhan jamur candida albicans dapat dilihat pada Gambar 3.

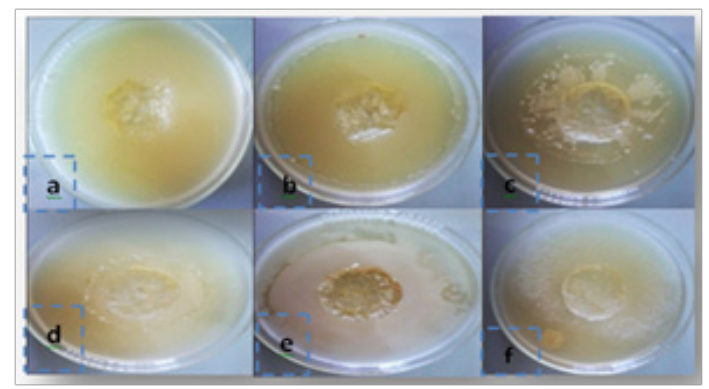

Gambar 3 uji daya hambat jamur Candida albicans (a) ekstrak buah kelor dengan pelarut aquades, ekstrak buah kelor dengan pelarut etanol 70\%, ekstrak buah kelor dengan pelarut heksana, kontrol (aquades), (e) kontrol (etanol $70 \%)$, dan (f) kontrol (heksana)

Berdasarkan gambar diatas terlihat bahwa ekstrak buah kelor dengan pelarut aquades memberikan hasil yang baik dibandingkan dengan pelarut etanol $70 \%$ dan heksana. Hal ini dibuktikan dengan melihat gambar diatas bahwa media dengan pelarut aquades tidak ditumbuhi jamur, tetapi untuk ekstrak buah kelor dengan pelarut etanol $70 \%$ terlihat bahwa pinggiran media ditumbuhi jamur dan terlebih pada media ekstrak buah kelor dengan pelarut heksana baik media maupun sumuran ditumbuhi jamur, sedangkan pada kontrol negatif dengan pelarut aquades hanya sebagian kecil yang tidak ditumbuhi jamur, terlebih lagi kontrol negatif dengan pelarut etanol $70 \%$ dan heksana hampir semua media dan sumuran yang ditumbuhi jamur. Berdasarkan hasil penelitian dapat dikatakan ekstrak buah kelor memiliki daya hambat terhadap pertumbuhan jamur candida albicans. Hal ini disebabkan karena ekstrak buah kelor mengandung zat antijamur. Berdasarkan hasil uji metabolit sekunder pada Tabel 1 diperoleh bahwa ekstrak buah kelor mengandung senyawa alkaloid, flavonoid dan steroid.

Alkaloid merupakan zat tumbuhan sekunder yang terbesar. Alkaloid merupakan suatu senyawa yang bersifat basa yang mengandung satu atau lebih atom nitrogen. Rahayu \& 
Rahayu (2009), menambahkan bahwa alkaloid memiliki sifat basa $\mathrm{pH}>7$ dan terasa pahit. Sifat basa ini kemungkinan akan menekan pertumbuhan jamur candida albicans, karena jamur tersebut tumbuh pada $\mathrm{pH}$ 4,5-6,5. Senyawa alkaloid diduga bekerja dengan cara memanfaatkan sifat reaksi gugus basa untuk bereaksi dengan gugus asam amino pada sel jamur. Alkaloid mempunyai aktivitas antijamur dengan cara mengganggu komponen penyusun peptidoglikon pada sel jamur sehingga lapisan dinding sel tidak terbentuk secara utuh dan menyebabkan kematian sel tersebut (Robinson, 1995).

Flavonoid merupakan senyawa yang mudah larut dalam pelarut polar seperti etanol, butanol dan aseton. Flavonoid merupakan golongan terbesar dari senyawa fenol, senyawa fenol memiliki sifat efektif menghambat pertumbuhan virus, bakteri dan jamur (Rahayu, 2013). Flavonoid yang terkandung dalam buah kelor diduga merupakan senyawa fenol. Mekanisme kerja flavonoid dalam menghambat jamur bekerja dengan cara denaturasi protein sehingga meningkatkan permeabilitas membran sel. Denaturasi protein menyebabkan gangguan dalam pembentukan sel sehingga merubah komposisi komponen protein, sehingga dengan terganggunya membran sel dapat menyebabkan meningkatnya permeabilitas sel sehingga menyebabkan kerusakan sel jamur. Kerusakan tersebut dapat menyebabkan kematian sel jamur (Rahayu, 2013). Hal ini sejalan dengan penelitian yang dilakukan oleh Dewi (2009), meneliti tentang uji aktivitas antijamur ekstrak buah pare belut, dimana berdasarkan penelitian diperoleh bahwa gugus flavonoid dapat bertindak sebagai antijamur karena memiliki senyawa fenol yang dapat mendenaturasi protein, dimana fenol dapat membentuk kompleks dengan ergosterol yang terdapat dalam membran sel jamur, kompleks tersebut menyebabkan pori-pori membesar pada sel jamur. Lewat pori-pori inilah komponen kecil dari isi sel jamur keluar seperti asam nukleat dan protein sehingga menyebabkan kematian pada jamur.

Steroid merupakan golongan lipid yang diturunkan dari senyawa jenuh yang dinamakan siklopentanoperhidrofenantrena, yang memiliki inti dengan empat cincin. Beberapa turunan steroid yang penting ialah alkohol steroid atau sterol. Steroid lain antara lain asam-asam empedu, hormon seks (androgen dan estrogen) dan hormon kortikosteroid. Senyawa steroid terdapat dalam setiap makhluk hidup. Steroid yang ditemukan dalam jaringan tumbuhan disebut fitosterol, sedangkan yang ditemukan dalam jaringan hewan disebut kolesterol (Robinson, 1995). Steroid diduga dapat menjadi senyawa antijamur dengan cara menghambat biosintesis asam nukleat, dengan mengakumulasi di dalam sel jamur dan mengubah komponen penyusun jamur itu sendiri.

\section{Kesimpulan}

Ekstrak buah kelor memiliki daya hambat terhadap pertumbuhan jamur candida albicans. $\mathrm{Hal}$ ini dapat dilihat dari hasil persentase daya hambat jamur dari ekstrak buah kelor dengan pelarut aquades, etanol $70 \%$, dan heksana secara berturut-turut yaitu 100\%, 59,99\%, dan 6,97\%. Ekstrak buah kelor dengan menggunakan pelarut aquades lebih besar dibandingkan dengan pelarut etanol $70 \%$ dan heksana, hal ini disebabkan karena adanya kandungan alkaloid, flavonoid dan steroid dalam buah kelor yang berfungsi menghambat pertumbuhan jamur candida albicans.

\section{Ucapan Terima Kasih}

Ucapan terima kasih penulis berikan kepada laboran laboratorium Agroteknologi Fakultas Pertanian Universitas Tadulako dan semua pihak yang banyak membantu penulis dalam menyelesaikan penelitian ini.

\section{Referensi}

Achmad, S. A. (1986). Buku materi pokok kimia organik bahan alam. Jakarta: Universitas Indonesia.

Bayu, A., \& Novairi, A. (2013). Pencegahan dan pengobatan herbal. Jogjakarta: Nusa Creativa.

Dewi, R. C. (2009). Uji aktivitas antijamur ekstrak buah pare belut (trichosanthes anguina l.). Universitas Sebelas Maret, Surakarta.

Dhayanti, A. P., Trisunurwati, P., \& Murwani, S. (2012). Efek antimikroba ekstrak n-heksana daun kelor (moringa oleifera lamk) terhadap esherichia coli secara in vitro. Journal of Pure and Applied Sciences, 3(1), 43-48.

Fahey. (2005). Moringa oleifera: A review of the medical evidence for its nutritional, therapeutik, and prophylactic properties. Trees for Life Journal, 1(5), 1-15.

Ganiswara, S. G. (1995). Farmakologi dan terapi bagian farmakologi. Jakarta: FKUI. 
Harbone, J. B. (1987). Metode fitokimia. Bandung: Penerbit ITB.

Krisnadi, A. D. (2012). Ebook kelor super nutrisi.[online]. Tersedia http://kelorina. com/. [13 November 2014].

Marliana, S. D., Suryati, V., \& Suyono. (2005). Skrining fitokimia dan analisis kromatografi lapis tipis komponen kimia buah labu siam (scehium edule jacq. swartz) dalam ekstrak etanol. Biofarmasi, 3(1), 26-35.

Mustikasari, K., \& Ariyani, D. (2010). Skrining fitokimia ekstrak metanol biji kalangkala (litsea angulata). Jurnal Sains dan Terapan Kimia, 4(2), 131-136.

Nepolean, P., Anitha, J., \& Renitta, R. E. (2009). Isolation, analysis and identification of phytochemicals of antimicrobial activity of moringa oleifera lam. Journal Current Biotica, 3(1), 33-39.

Pandey, A., Tripathi, P., Gupta, P. P., Haider, J., Bhatt, S., \& Singh, A. V. (2012). Moringa oleifera lamk - a plant with a plethora of diverse therapeutic benefits. Journal Medicinal and Aromatic Plants, 1(1), 1-8.

Rahayu, P. (2013). Konsentrasi hambat minimum buah belimbing wuluh (averrhoa bilimbi) terhadap pertumbuhan jamur candida albicans. Universitas Hasanuddin, Makassar.

Rahayu, T., \& Rahayu, T. (2009). Uji antijamur kombucha coffee terhadap candida albicans dan tricophyton mentagrophytes. Jurnal Penelitian Sains \& Teknologi, 10(1), 10-17.
Robinson, T. (1995). Kandungan organik tumbuhan tinggi. Bandung: Penerbit ITB.

Sangi, M., Runtuwene, M. R. J., Simbala, H. E. I., \& Makang, V. M. A. (2008). Analisis fitokimia tumbuhan obat di kabupaten minahasa utara. Chemistry Program, 1(1), 47-53.

Sayeed, M. A., Hossain, M. S., Chowduny, M. E. H., \& Haque, M. (2012). In vitro antimicrobial activity of methanolic extract of moringa oleifera fruits. Journal of Pharmacognosy and Phytochemistry, 1(4), 94-98.

Septianingsih, S. F. (2013). Uji aktivitas antioksidan ekstrak bawang butan (eleutherine palmifolia merr). Universitas Tadulako, Palu.

Simatupang, M. M. (2009). Candida albicans. Sumatra Utara: Penelitian dosen departemen mikrobiologi Fakultas Kedokteran USU.

Sjahid, L. R. (2008). Isolasi dan identifikasi flavonoid dari daun dewandaru (eugenia uniflora L). Universitas Muhammadiyah, Surakarta.

Svehla. (1985). Analisis anorganik kualitatif makro dan semimikro edisi kelima, bagian I. Jakarta: Kalman Media Pustaka.

Widowati, I., Efiyati, S., \& Wahyuningtyas, S. (2014). Uji aktivitas antibakteri ekstrak daun kelor (moringa oleifera lamk) terhadap bakteri pembusuk ikan segar (pseedoonas aeruginosa). PELITA, 9(1), 146-157. 